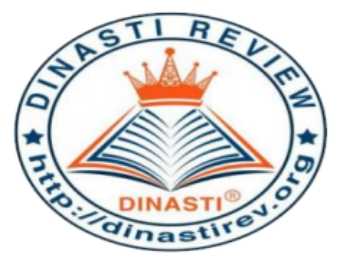

\title{
ANALISIS SWOT UNTUK MERUMUSKAN STRATEGI BERSAING PADA PT. MENARA ANGKASA SEMESTA CABANG SENTANI
}

Iqbal Kamaluddin ${ }^{1)}$

1) Universitas Mercu Buana, Jakarta, Indonesia

ARTICLE INFORMATION

Received: 4 April 2020

Revised: 14 April 2020

Issued: 25 April 2020

Corresponding author:

Iqbal Kamaluddin

E-mail:

iqbalkamaluddin88@gmail.com

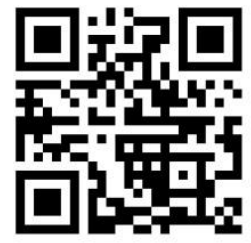

DOI:10.31933/JIMT
Abstrak: PT Menara Angkasa Semesta Cabang Sentani adalah perusahaan swasta yang bergerak di bisnis jasa tata operasi darat atau biasa dikenal dengan istilah ground handling yang berdiri di tahun 2013. Perusahaan belum memiliki perumusan strategic planning yang telah melalui proses analisis sehingga memungkinkan perusahaan untuk dapat tumbuh dan berkembang di masa yang akan datang. Penelitian ini bertujuan untuk mengidentifikasi faktor internal kekuatan (Stregths) dan peluang (Opportunities), dan faktor kelemahan (Weaknesses) dan ancaman (Threats), selain itu agar dapat merumuskan strategi bisnis perusahaan dan memberikan usulan atau rekomendasi strategi bisnis yang digunakan perusahaan. Hasil pnelitian diharapkan menjadi tolak ukur atau pijakan untuk menyusun suatu perencanaan yang baik di masa yang akan datang dan merupakan suatu analisis yang efektif bagi perkembangan perusahaan. Metode yang digunakan dalam penelitian ini adalah metode deskriptif dengan pendekatan kualitatif dengan menggunakan teknik pengumpulan data terdiri dari: Tahap pengumpulan data (evaluasi faktor eksternal dan internal), analisis SWOT, matriks strategi IFAS EFAS, dan matriks IE. Hasil tabel IFAS dan EFAS didapatkan nilai IFAS sebesar 2.88 dan skor untuk hasil EFAS sebesar 2.78, dan apabila dikonversikan kedalam gambar diagram IE Matriks, maka hasilnya terletak di kuadran V, artinya perusahaan masuk kedalam fase pertumbuhan dan stabilitas (growth and stability).

Kata Kunci : Analisis SWOT, Strategi Pemasaran, IFAS, EFAS, Matriks IE

\section{PENDAHULUAN}

Kondisi persaingan bisnis yang semakin ketat terutama bisnis di dunia penerbangan yang merupakan salah satu bisnis yang popular dalam beberapa tahun belakangan ini , banyak nya perusahan - perusahan penerbangan baru yang bermunculan sehingga berbanding lurus dengan bertambahnya perusahaan - perusahaan yang bergerak dalam jasa tata operasi darat 
atau biasa dikenal dengan istilah ground handling, dengan demikian perusahaan membutuhkan strategi agar dapat bertahan atau bahkan memenangkan persaingan.

PT. Menara Angkasa Semesta Cabang Sentani adalah perusahaan yang berdiri sejak 05 Februari Tahun 2013 yang berdomisili di Jalan Yabaso Kecamatan Sentani Jayapura, PT. Menara Angkasa Semesta Cabang Sentani merupakan salah satu cabang dari perusahaan induk PT. Menara Angkasa Semesta yang yang berdomisili di Makasssar. PT. Menara Angkasa Semesta Cabang Sentani merupakan perusahaan yang bergerak pelayanan jasa tata operasi darat ( ground handling ) yang mengutamakan kualitas keselamatan.

Adapun ruang lingkup pekerjaan PT. Menara Angkasa Semesta Cabang Sentani sebagai penyedia jasa ground handling adalah sebagai berikut:

1. Pre-flight

Merupakan kegiatan penanganan terhadap penumpang beserta bagasi, kargo serta pos dan pesawat sebelum pesawat berangkat dari bandar udara asal.

2. Post Flight

Merupakan kegiatan penanganan terhadap penumpang beserta bagasinya dan kargo serta pos dan pesawat setelah pesawat parkir di apron bandar udara tujuan.

Aktivitas bisnis PT Menara Angkasa Semesta Cabang Sentani yang telah menjalankan usahanya sejak tahuin 2013 telah menunjukan kinerja yang positif , namun dalam beberapa tahun ini karena ketatnya persaingan bisnis yang ada menuntut PT. Menara Angkasa Semesta Cabang Sentani untuk mengantisipasi hal tersebut melalui perumusan strategic planning yang memungkinkan perusahaan untuk terus tumbuh dan berkembang di masa yang akan datang. Pengembangan perusahaan dapat dilakukan dengan cara menerapkan manajemen strategi yang baik agar perusahaan dapat mengevaluasi kinerja keseluruhan perusahaan serta berkala sehingga dapat diketahui faktor - faktor apa saja yang menghambat kemajuan dari perusahaan tersebut dan dapat segera di cari penanggulangannya, selain itu untuk mencari faktor - faktor apa saja yang merupakan kekuatan perusahaan agar dapat dikembangkan bagi keuntungan dan kekuatan bersaing perusahaan di industri jasa layanan ground handling. Persaingan yang bersifat global dan tajam dalam industri jasa layanan ground handling menyebabkan banyak perusahaan yang mengalami kebangkrutan karena kalah dalam bersaing.

Berdasarkan penjelasan diatas, identifikasi masalah yang dapat dirumuskan adalah: bagaimana mengidentifikasi kondisi faktor internal kekuatan (Strengths) dan peluang (Opportunities), serta faktor kelemahan (Weaknesses) dan ancaman (Threats) PT. Menara Angkasa Semesta Cabang Sentani, dan bagaimana memformulasikan strategi bisnis untuk PT. Menara Angkasa Semesta dalam meningkatkan daya saing perusahaan.

Sedangkan tujuan dari penelitian ini adalah untuk mengidentifikasi kondisi faktor internal kekuatan (Strengths) dan peluang (Opportunities), serta faktor kelemahan (Weaknesses) dan ancaman (Threats) PT. Menara Angkasa Semesta Cabang Sentani, serta merumuskan strategi bisnis PT. Menara Angkasa Semesta Cabang Sentani dan memberikan usulan atau rekomendasi strategi bisnis yang digunakan perusahaan. Hasil pnelitian diharapkan menjadi tolak ukur atau pijakan untuk menyusun suatu perencanaan yang baik di masa yang akan datang dan merupakan suatu analisis yang efektif bagi perkembangan perusahaan. 


\section{TINJAUAN PUSTAKA}

Untuk mempertahankan keberlangsungan bisnis perusahaan, pimpinan perusahaan senantiasa dituntut untuk berfikir secara strategis mengenai posisi dan kemampuan kompetitif perusahaannya dan pengaruh perkembangan lingkungan luar terhadap perusahaannya. Pimpinan perusahaan harus mengetahui strategi yang harus dibuat dalam menghadapi suatu perubahan atau situasi tertentu. Menurut Nadela dan Paun (2019), strategi adalah sebuah kerangka kerja atas segala sesuatu yang penting, seperti kewirausahaan, persaingan dan fungsional yang akan diterapkan untuk mewujudkan tujuan perusahaan serta posisi perusahaan untuk mendapatkan keberhasilan yang berkesinambungan. Menurut David (2011), tujuan akhir strategi perusahaan yaitu dalam rangka mempertahankan posisi bersaingnya, bahkan jika dimungkinkan untuk dapat meningkatkan penguasaan produk di pasar.

Proses manajemen strategi ada tiga tahap, yaitu perumusan strategi (strategic formulation), implementasi strategi (strategic implementation) dan evaluasi strategi (strategic evaluation), David (2009:6), perumusan startegi dengan mengenali peluang (Opportunities) dan ancaman (threats) dari eksternal perusahaan, menetapkan kekuatan dan kelemahan internal, menetapkan tujuan jangka panjang, mengembangkan bisnis, serta menghasilkan strategi alternatif, dan memilih strategi tertentu untuk dilaksanakan, strategi berbeda dengan mengelola operasi, tetapi keduanya sangat penting, dan perlu diintegrasikan. Sedangkan strategi visioner yang tidak dikaitkan dengan keunggulan proses operasi dan tata Kelola (governance) tidak dapat diterapkan,Porter (1996), dan menurut Kaplan dan Norton (2008) keunggulan operasi bisa menurunkan biaya, dapat mengurangi jumlah proses, dapat memperbaiki mutu, dan serta mengurangi waktu tunggu, tetapi tanpa visi dan panduan dari strategi, perusahaan tidak mungkin menikmati kesuksesan yang berkisanambungan hanya dengan perbaikan operasi semata.

Untuk mengatasi ancaman eksternal dan merebut peluang yang ada perusahaan dapat mengembangkan strateginya melalui proses analisis, perumusan dan evaluasi strategi, strategi tersebut dinamakan perencanaan strategi. Menurut Rangkuti (1998:3), perencanaan strategi memiliki tujuan utama yaitu agar perusahaan dapat melihat secara obyektif kondisi - kondisi perusahaannya baik pada internal maupun eksternal, sehingga perusahaan dapat mengantisipasi perubahan lingkunan eksternal. Rancangan keseluruhan perusahaan dalam menentukan target pasar dan memuaskan konsumen dengan membangun kombinasi elemen dari bauran pemasaran; produk, distribusi, promosi, dan harga adalah pengertian dari strategi pemasaran, Kurtz (2008). Menurut Eddy (2016), manajemen strategis terdiri atas sembilan tugas penting diantaranya:

1. Merumuskan misi perusahaan.

2. Melakukan suatu analisis mengenai kondisi dan kemampuan dari internal perusahaan.

3. Menilai lingkungan eksternal perusahaan.

4. Mengidentifikasi pilihan yang paling menguntungkan untuk perusahaan yaitu dengan cara mengevaluasi setiap pilihan sesuai dengan misi perusahaan.

5. Mengimplementasikan strategi yang telah dipilih melalui alokasi sumberdaya.

6. Melakukan analisa terhadap pilihan - pilihan yang dimiliki oleh perusahaan.

7. Mengembangkan tujuan tahunan dan strategi jangka pendek.

8. Menentukan satu set tujuan jangka panjang dan strategis utama.

9. Melakukan evaluasi terhadap keberhasilan proses strategis sebagai masukan dalam mengambil pengambilan keputusan di masa yang akan datang.

\section{Analisis SWOT}

Menurut Rangkuti (2009:19) analisis SWOT merupakan sebuah metode perencanaan strategis yang digunakan untuk mengevaluasi Srengths, Weakness, Opportunities, dan 
Threats terlibat dalam suatu proyek atau dalam bisnis usaha, hal ini melibatkan dalam penentuan sasaran atau tujuan usaha bisnis perusahaan atau proyek dan mengidentifikasi faktor - faktor internal dan eksternal yang baik dan menguntungkan untuk mencapai tujuan itu. Analisis SWOT ini didasari pada logika dengan cara memaksimalkan (Strengths) dengan (Opportunities) faktor internal perusahaan, meminimalkan (Weaknesses) dengan ancaman (Threats) faktor eksternal perusahaan, proses dalam pengambilan keputusan strategis yang selalu berkaitan dengan pengembangan misi perusahaan, tujuan perusahaan, strategi perusahaan, dan kebijakan perusahaan. Perencana strategi harus menganalisis faktor - faktor strategi perusahaan yaitu kekuatan (Strengths), kelemahan (Weaknesses), Peluang (Opportunities), dan Ancaman (Threats), dalam kondisi yang ada saat ini. Hal ini disebut dengan analisis situasi.

SWOT merupakan identitas dari berbagai faktor secara sistematis untuk merumuskan suatu strategi pelayanan, analisis ini berdasarkan logika yang dapat memaksimalkan peluang (Opportunities), dan dapat meminimalisir kelemahan (Weaknesses) perusahaan dan ancaman (Threats ) perusahaan, yaitu membandingkan antara faktor eksternal perusahaan dan faktor internal perusahaan, Rangkuti (2009) Diagram analisis SWOT:

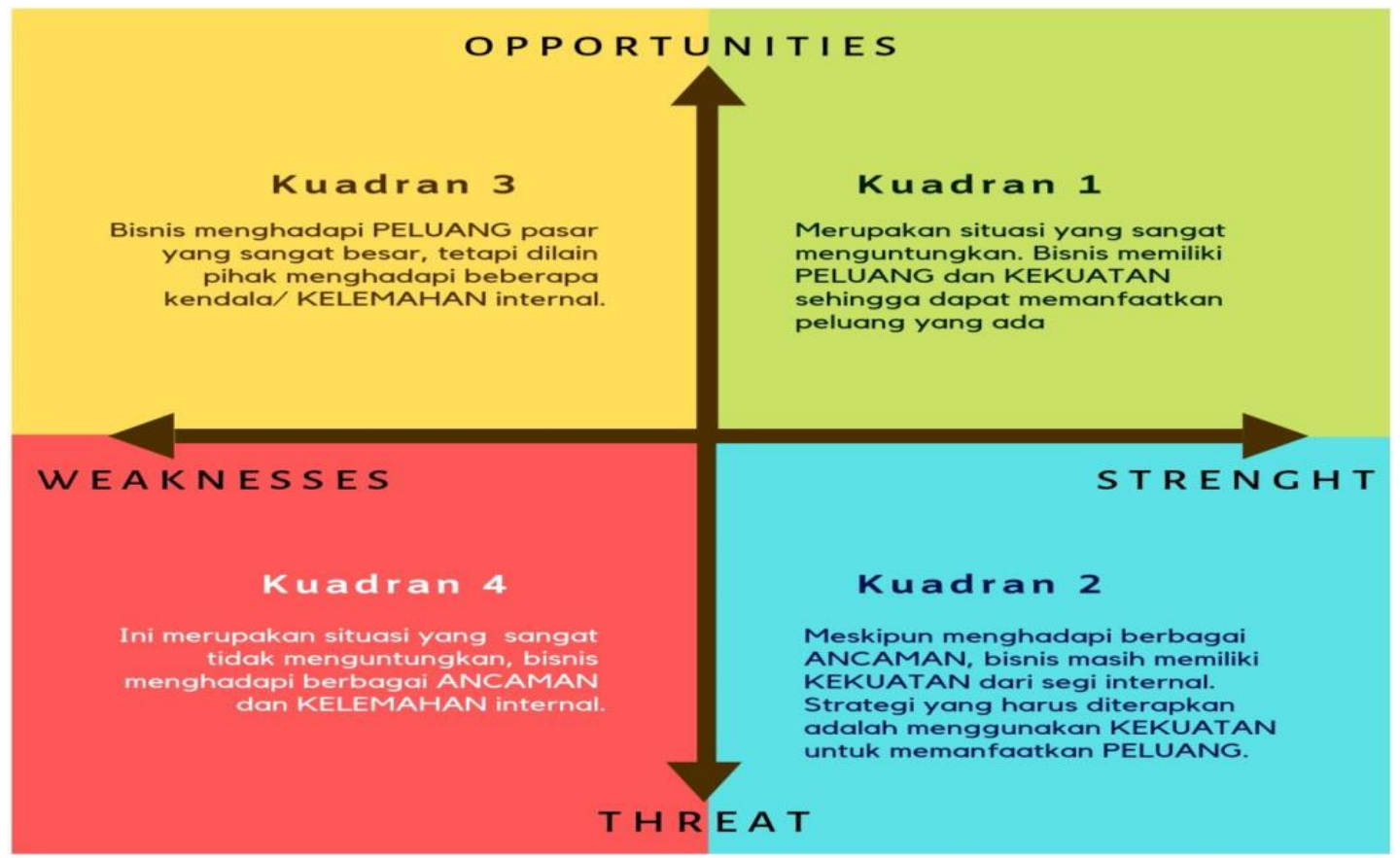

Gambar 1 Diagram SWOT Analysis

\section{Matriks SWOT}

Matriks SWOT merupakan suatu alat yang dapat digunakan untuk menyusun faktor faktor strategis perusahaan, matriks SWOT ini dapat menggambarkan bagaimana peluang dan ancaman eksternal yang dihadapi perusahaan dapat disesuaikan oleh perusahaan dengan kekuatan dan kelemahan yang dimilikinya, matriks SWOT ini mengahasilkan empat set kemungkinan alternatif strategis dengan kata lain matriks SWOT dapat digunakan untuk menentukan keputusan atau kebijakan strategis perusahaan. 


\begin{tabular}{|l|l|l|}
\hline \multicolumn{1}{|c|}{ IFAS } & $\begin{array}{l}\text { S (Strength) } \\
\text { Tentukan faktor2 } \\
\text { kekuatan internal }\end{array}$ & $\begin{array}{l}\text { W (Weakness) } \\
\text { Tentukan faktor2 } \\
\text { kelemahan internal }\end{array}$ \\
\hline $\begin{array}{l}\text { O (Opportunity) } \\
\text { Tentukan faktor2 } \\
\text { peluang eksternal }\end{array}$ & $\begin{array}{l}\text { Strategi SO: Ciptakan } \\
\text { strategi yang } \\
\text { menggunakan kekuatan } \\
\text { untuk memanfaatkan } \\
\text { peluang }\end{array}$ & $\begin{array}{l}\text { Strategi WO: Ciptakan } \\
\text { strategi yang } \\
\text { meminimalkan } \\
\text { kelemahan untuk } \\
\text { memanfaatkan peluang }\end{array}$ \\
\hline $\begin{array}{l}\text { Tentukan faktor2 } \\
\text { Tencaman eksternal }\end{array}$ & $\begin{array}{l}\text { Strategi ST: Ciptakan } \\
\text { strategi yang } \\
\text { menggunakan kekuatan } \\
\text { untuk mengatasi } \\
\text { ancaman }\end{array}$ & $\begin{array}{l}\text { Strategi WT: Ciptakan } \\
\text { strategi yang } \\
\text { meminimalkan } \\
\text { kelamahan dan } \\
\text { menghindari ancaman }\end{array}$ \\
\hline
\end{tabular}

Gambar 2 Matrik SWOT

\section{METODE PENELITIAN}

\section{Jenis Penelitian}

Penelitian ini adalah penelitian yang membahas manajemen pemasaran, melakukan analisis SWOT untuk menentukan strategi bisnis PT. Menara Angkasa Semesta Cabang Sentani. Untuk pengumpulan data pada penelitian ini penulis melakukan pengumpulan data melalui Teknik wawancara yaitu melalui komunikasi lewat handphone dan media sosial dengan pimpinan perusahaan PT. Menara Angkasa Semesta Cabang Sentani dan sejumlah karyawan yang berhubungan dengan penelitian ini, tujuan dari wawancara tersebut untuk mencari kekuatan, kelemahan, peluang dan ancaman dari PT. Menara Angkasa Semesta Cabang Sentani.

Metode penelitian yang diterapkan dalam penelitian ini adalah dengan metode penelitian deskriptif yaitu dengan metode pendekatan kualitatif. Pendekatan kualitatif merupakan suatu pendekatan yang menggunakan data berupa kalimat tertulis atau lisan, fenomena, perilaku peristiwa - peristiwa, pengetahuan dan obyek studi yang diamati oleh peneliti. Sedangkan analisis deskriftif adalah gambaran suatu jenis yang penyajian datanya diperoleh dari hasil penelitian yaitu dengan memberikan gambaran kepada peneliti yang sesuai dengan kenyataan pada perusahaan ataupun fakta - fakta yang ada pada saat diadakan penelitian. Menurut Sugiono (2010), metode penelitian kualitatif merupakan metode penelitian dengan landasan filsafat postpositivisme, dan digunakan pada kondisi obyek yang alamiah, dimana peneliti adalah instrument kunci. Dengan metode pendekatan kualitatif yang sesuai dengan kenyataan dan fakta - fakta di tempat penelitian diharapkan akan membantu peneliti memperoleh data yang relevan dengan penelitian.

\section{Teknik Pengumpulan Data}

Menurut Umar (2003), sumber data yang digunakan dalam penelitian ini adalah data primer dan jenis data adalah kualitatif. Data primer merupakan sumber data yang diperoleh secara langsung oleh peneliti terhadap obyek yang diteliti sedangkan data kualitatif data yang dapat diperoleh penulis dari wawancara dengan nara sumber atau pihak - pihak yang berkepentingan berupa data yang diterima secara lisan dengan penjelasan mengenai pembahasan. Metode pengumpulan data yang digunakan dalam penilitian ini adalah wawancara lewat media (handphone dan media sosial), dokumentasi dan triangulasi. Penelitian ini menggunakan triangulasi sumber dimana data yang didapatkan dari informan lainnya. Dengan demikian pengujian datanya melibatkan berbagai sumber. 


\section{Teknik Analisis Data}

Teknik analisis data yang digunakan oleh penulis dalam melakukan penelitian ini adalah deskriftif kualitatif, yaitu dengan cara mengumpulkan data - data dari pimpinan, dan Karyawan PT. Menara Angkasa Semesta Cabang Sentani , mengolah data tersebut, dan menyajikan data yang diperoleh dan diolah sehingga dapat memberikan keterangan yang lengkap dan benar agar pihak lain lebih mudah mendapatkan gambaran mengenai sifat (karakteristik) obyek dari data tersebut.

\section{Tahap pengumpulan data.}

Pada tahapan ini penulis tidak hanya sekedar melakukan kegiatan pengumpulan data akan tetapi juga merupakan suatu kegiatan pengklasifikasian atau mengelompokkan data data tersebut dan pra analisis dimana tahap ini dibagi menjadi dua bagian yaitu data internal dan data eksternal, kemudian mengevaluasi kedua faktor tersebut, baik faktor eksternal maupun faktor internal perusahaan.

\section{Tahap analisis SWOT}

Dalam melakukan sebuah perencanaan bisnis di perusahaan kita harus melakukan evaluasi faktor eksternal maupun faktor internal yang berhubungan dengan kegiatan bisnis perusahaan tersebut. Analisis faktor - faktor harus menghasilkan adanya kekuatan (strength), serta kelemahan (weakness) yang terdapat pada perusahaan. Sedangkan untuk melakukan analisis terhadap faktor eksternal harus dapat menghasilkan informasi terkait kesempatan kesempatan yang dimiliki oleh perusahaan atau peluang (opportunity) serta dapat ancaman yang membahayakan perusahaan dan yang dialami oleh organisasi yang bersangkutan. Setelah kita mendapatkan data kekuatan, kelemahan, kesempatan yang terbuka, serta ancaman - ancaman yang dialaminya, maka kita dapat menyusun suatu rencana atau strategi yang mencakup tujuan yang telah ditentukan perusahaan. Menurut Utami (2012), matriks SWOT adalah mengkombinasikan peluang, ancaman, kekuatan, dan kelemahan dalam sebuah matriks, matriks tersebut terdiri atas empat kuadran, yang mana tiap - tiap kuadran memuat masing - masing strategi didalamnya.

\section{Matriks Strategi IFAS EFAS}

Tahapan - tahapan untuk menentukan nilai faktor internal dan eksternal suatu perusahaan adalah sebagai berikut:

1. Buatlah kolom masing - masing, dan kelompokanlah kedalam faktor internal dan faktor eksternal perusahaan

2. Berikan bobot pada masing - masing faktor tersebut pada kolom 2, diawali dengan angka 1,0 (yang memiliki arti sangat penting) sampai dengan angka 0,0 (yang memiliki arti tidak penting). Faktor - faktor akan berdampak pada faktor strategis.

3. Setelah diberikan bobot pada masing - masing faktor kemudian hitunglah rating (kolom 3), diberikan skala mulai dari 4 (outstanding) sampai dengan 1 (poor) skala tersebut dilihat pengaruh faktor tersebut dan dihubungkan dengan pengaruh terhadap perusahaan. Untuk rating faktor peluang bersifat positif. Peluang semakin besar diberi nilai +4 , namun jika kecil diberi nilai +1 , sedangkan rating ancaman kebalikannya. Jika nilai ancaman paling besar maka dikasih nilai 1, namun jika nilai ancaman kecil ratingnya diberi nilai 4.

4. Setelah menentukan rating peluang dan ancaman langkah berikutnya menkalikan bobot di kolom 2 terhadap rating di kolom 3, sehingga faktor pembobotan di kolom 4 dapat diperoleh, hasil dari perkalian adalah skor pembobotan mulai dari angka 4,0 yang artinya adalah outstanding sampai angka 1,0 yang artinya poor.

5. Langkah berikutnya adalah dengan mentotalkan skor dikolam 4. Nilai total ini dapat memperlihatkan reaksi perusahaan terhadap faktor - faktor strategis eksternal. 


\section{Matriks IE}

Matriks internal - eksternal telah dikembangkan oleh model General Electric (GE Model). Sumbu horizontal pada matriks IE menunjukkan skor total IFAS, pada sumbu vertical menunjukan skor nilai EFAS, sedangkan pada sumbu horizontal skor antara 1,00 sampai 1,99 menunjukan posisi internal lemah. Skor 2,00 sampai 2,99 menunjukan rata - rata . Skor 3,00 sampai 4,00 menunjukan posisi internal kuat. Begitu juga pada sumbu vertikal yang menunjukan pengaruh eksternal.

\section{HASIL DAN PEMBAHASAN}

\section{Faktor Internal dan Eksternal}

Faktor internal merupakan faktor yang berasal dari dalam lingkungan industri yang berupa kekuatan dan kelemahan dari PT. Menara Angkasa Semesta Cabang Sentani, sedangkan faktor eksternal merupakan faktor yang berasal dari luar lingkungan industri berupa peluang dan ancaman. Tabel 1 berikut menunjukan faktor internal dari PT. Menara Angkasa Semesta Cabang Sentani.

\section{Matriks IFAS EFAS}

Menurut Wiagustini dan Permatawati (2015) setelah identifikasi faktor langkah selanjutnya adalah perhitungan bobot dan rating yang berfungsi sebagai landasan penentuan posisi perusaahaan dalam bisnis. Hal ini penting diketahui sebagai dasar perusahaan untuk menjalankan strategi bisnis yang sesuaai dengan kondisi perusahaan. Bobot ditentukan mulai dari angka $0-1$, artinya hasil akumulasi dari kekuatan dibandingkan kelemahan dan hasil akumulasi dari peluang dibandingkan dengan ancaman. Nilai pada bobot ditentukan dari hasil wawancara oleh penulis dengan pimpinan, dan karyawan PT. Menara Angkasa Semesta Cabang Sentani, sedangkan rating ditentukan dengan tingkat pengaruh faktor tersebut terhadap PT. Menara Angkasa Semesta Cabang Sentani, rating yang paling berpengaruh adalah rating 1, sedangkan rating 4 paling sedikit pengaruhnya, penentuan rating tersebut merupakan hasil diskusi dengan pimpinan dan karyawan PT. Menara Angkasa Semesta Cabang Sentani.

Skor $=$ Rating $\mathrm{x}$ Bobot

Tabel 1. Faktor Internal

\begin{tabular}{cll}
\hline No & \multicolumn{1}{c}{ Kekuatan } & \multicolumn{1}{c}{ Kelemahan } \\
\hline 1 & $\begin{array}{l}\text { Perusahaan memiliki ijin operasi dari } \\
\text { Direktorat Jenderal Perhubungan Udara }\end{array}$ & Kurangnya modal \\
\hline 2 & $\begin{array}{l}\text { Karyawan memiliki sertifikat kecakapan } \\
\text { untuk mengoperasikan peralatan } \\
\text { Ground Support Equipment }(G S E)\end{array}$ & $\begin{array}{l}\text { Kurangnya alat Ground Support } \\
\text { Equipment }(G S E)\end{array}$ \\
\hline 3 & $\begin{array}{l}\text { Peralatan memiliki sertifikat kelaiakan } \\
\text { yang dikeluarkan oleh Direktorat } \\
\text { Jenderal Perhubungan Udara }\end{array}$ & Hanya melayani pesawat kargo \\
\hline 4 & $\begin{array}{l}\text { Memiliki hubungan yang baik dengan } \\
\text { konsumen }\end{array}$ & Peralatan yang sudah aging \\
\hline
\end{tabular}

Tabel 2. Faktor Eksternal

No Peluang Ancaman




\begin{tabular}{cll}
\hline 1 & Pasar bisnis yang masih tinggi & $\begin{array}{l}\text { Munculnya perusahaan baru dengan } \\
\text { menawarkan pelayanan jasa yang sama }\end{array}$ \\
\hline 2 & $\begin{array}{l}\text { Harga layanan jasa ground handling di } \\
\text { Sentani yang relatif tinggi }\end{array}$ & Peraturan pemerintah yang berubah - ubah \\
\hline 3 & $\begin{array}{l}\text { Program percepatan pemerintah } \\
\text { terhadap pembangunan di Papua }\end{array}$ & $\begin{array}{l}\text { Pengelolaan bandar udara dikelola oleh } \\
\text { PT. Angkasa Pura I, menyebabkan biaya } \\
\text { konsesi yang tinggi }\end{array}$ \\
\hline 4 & $\begin{array}{l}\text { Sembako, Bahan Bakar Minyak (BBM) } \\
\text { dan kebutuhan lainnya di angkut melalui } \\
\text { jalur udara }\end{array}$ & $\begin{array}{l}\text { Kompetitor berani bersaing dengan harga } \\
\text { yang dipatok lebih murah }\end{array}$ \\
\hline
\end{tabular}

Tabel 3. Perhitungan Bobot dan Rating

\begin{tabular}{|c|c|c|c|c|}
\hline \multicolumn{5}{|c|}{ Sterngth (Kekuatan) } \\
\hline No & Faktor & Bobot & Rating & Skor \\
\hline 1 & $\begin{array}{l}\text { Perusahaan memiliki ijin operasi dari Direktorat } \\
\text { Jenderal Perhubungan Udara }\end{array}$ & 0,13 & 3 & 0,39 \\
\hline 2 & $\begin{array}{l}\text { Karyawan memiliki sertifikat kecakapan untuk } \\
\text { mengoperasikan peralatan Ground Support Equipment } \\
(\text { GSE) }\end{array}$ & 0,12 & 3 & 0,36 \\
\hline 3 & $\begin{array}{l}\text { Peralatan memiliki sertifikat kelaiakan yang dikeluarkan } \\
\text { oleh Direktorat Jenderal Perhubungan Udara }\end{array}$ & 0,12 & 2 & 0,24 \\
\hline 4 & Memiliki hubungan yang baik dengan konsumen & 0,14 & 4 & 0,56 \\
\hline Jun & lah Skor Kekuatan & $\mathbf{0 , 5 1}$ & & $\mathbf{1 , 5 5}$ \\
\hline \multicolumn{5}{|c|}{ Weakness (Kelemahan) } \\
\hline No & Faktor & Bobot & Rating & Skor \\
\hline 1 & Kurangnya modal & 0,13 & 3 & 0,39 \\
\hline 2 & Kurangnya peralatan & 0,12 & 2 & 0,24 \\
\hline 3 & Hanya melayani pesawat kargo & 0,13 & 2 & 0,26 \\
\hline & Peralatan yang sudah aging & 0,11 & 4 & 0,44 \\
\hline Jun & lah Skor Kelemahan & $\mathbf{0 , 4 9}$ & & 1,33 \\
\hline Tot & l (Kekuatan + Kelemahan) & $\mathbf{1 , 0 0}$ & & 2,88 \\
\hline \multicolumn{5}{|c|}{ Opportunities (Peluang) } \\
\hline No & Faktor & Bobot & Rating & Skor \\
\hline 1 & Pasar bisnis yang masih tinggi & 0,15 & 4 & 0,60 \\
\hline 2 & $\begin{array}{l}\text { Harga layanan jasa ground handling di Sentani yang } \\
\text { relatif tinggi }\end{array}$ & 0,12 & 2 & 0,24 \\
\hline 3 & $\begin{array}{l}\text { Program percepatan pemerintah terhadap pembangunan } \\
\text { di Papua }\end{array}$ & 0,14 & 3 & 0,42 \\
\hline 4 & $\begin{array}{l}\text { Sembako, Bahan Bakar Minyak (BBM) dan kebutuhan } \\
\text { lainnya di angkut melalui jalur udara }\end{array}$ & 0,13 & 3 & 0,39 \\
\hline Jun & lah Skor Peluang & $\mathbf{0 , 5 4}$ & & $\mathbf{1 , 6 5}$ \\
\hline \multicolumn{5}{|c|}{ Threats (Ancaman) } \\
\hline No & Faktor & Bobot & Rating & Skor \\
\hline 1 & $\begin{array}{l}\text { Munculnya perusahaan baru dengan menawarkan } \\
\text { pelayanan jasa yang sama }\end{array}$ & 0,12 & 2 & 0,24 \\
\hline 2 & Peraturan pemerintah yang berubah - ubah & 0,13 & 2 & 0,26 \\
\hline 3 & Pengelolaan bandar udara dikelola oleh PT. Angkasa & 0,11 & 3 & 0,33 \\
\hline
\end{tabular}




\begin{tabular}{llll}
\hline \multicolumn{4}{l}{ Pura I, menyebabkan biaya konsesi yang tinggi } \\
\hline $\begin{array}{l}\text { Kompetitor berani bersaing dengan harga yang dipatok } \\
\text { lebih murah }\end{array}$ & 0,10 & 3 & 0,30 \\
\hline Jumlah Skor Ancaman & $\mathbf{0 , 4 6}$ & $\mathbf{1 , 1 3}$ \\
\hline Total (Peluang + Ancaman) & $\mathbf{1 , 0 0}$ & $\mathbf{2 , 7 8}$ \\
\hline
\end{tabular}

Menurut Tjoe dan Sarjono (2010), setelah itu dilakukan penentuan alternatif strategi berdasarkan analisi SWOT. Untuk menentukan posisi dalam matriks SWOT, maka dilakukan dua perhitungan. Pertama jumlahkan total skor kekuatan, dan total skor kelemahan, misalnya skor kekuatan nilainya positif, sedangkan skor kelemahan nilainya dominan, jika ternyata hasilnya positif, maka artinya bahwa faktor kekuatan lebih dominan dibandingkan dengan skor kelemahan kedua, total skor peluang dan total skor ancaman dijumlahkan, misalnya skor peluang, nilainya positif, sedangkan skor ancaman nilainya dominan. Jika ternyata hasilnya positif, maka artinya bahwa faktor peluang lebih dominan dibandingkan dengan skor ancaman. Dari kesimpulan tersebut dengan menggunakan matrik SWOT, penulis dapat menyusun 4 strategi utama, yaitu (S-O) , (W-O), (S-T), dan (W-T). Masing - masing strtegi tersebut memiliki ciri tersendiri dan nanti dalam implementasinya, dilaksanakan secara bersama-sama dan saling mendukung satu sama lain.

1. S-O (Strength-Opportunities)

Strategi ini mengandung pengertian bahwa berbagai alternatif strategi yang bersifat memanfaatkan peluang dengan mendayagunakan kekuatan atau kelebihan yang dimiliki oleh perusahaan.

2. W-O (Weaknesses - Opportunities)

Strategi ini mengandung pengertian bahwa dalam kategori yang bersifat memanfaatkan peluang eksternal dapat digunakan untuk mengatasi kelemahan.

3. (Strengths - Threats)

Strategi ini mengandung pengertian bahwa dalam kategori alternatif strategi yang memanfaatkan kekuatan dapat digunakan untuk mengatasi ancaman.

4. W-T (Weaknesses - Threats)

Strategi ini mengandung pengertian bahwa dalam kategori alternatif strategi sebagai solusi dari penilaian atas kelemahan dan ancaman yang dihadapi, atau salah satu usaha menghindari ancaman untuk mengatasi kelemahan.

Alternatif strategi ditunjukan pada table 3. Berdasarkan hasil analisis penulis pada diagram SWOT di table 3 dan hasil penilaian penulis pada table EFAS dan IFAS, dapat disimpulkan bahwa kekuatan PT. Menara Angkasa Semesta Cabang Sentani lebih besar dari kelemahannya dan peluang PT. Menara Angkasa Semesta Cabang Sentani lebih besar dari ancamannya maka dapat disimpulkan perusahaan berada dalam kuadran 1 dengan strategi agresif yang sesuai dengan SO pada matrik SWOT.

Berikut rangkuman strategi S - O yang layak dilakukan oleh PT. Menara Angkasa Semesta Cabang Sentani:

1. Perusahaan memiliki ijin operasi dari Direktorat Jenderal Perhubungan Udara, dan karyawan memiliki sertifikat kecakapan untuk mengoperasikan peralatan Ground Support Equipment (GSE) sehingga pasar bisnis yang masih tinggi dapat dicapai dengan jangkauan yang luas, sehingga menjadikan PT. Menara Angkasa Semesta Cabang Sentani semakin berkembang dan market terbuka dengan luas.

2. Peralatan memiliki sertifikat kelaiakan yang dikeluarkan oleh Direktorat Jenderal Perhubungan Udara sehingga dapat memberikan nilai tambah dan nilai jual menjadi lebih tinggi. 


\begin{tabular}{|c|c|c|}
\hline SWOT MATRIX & $\begin{array}{l}\text { Kekuatan (Strengths) } \\
\text { 1. Perusahaan memiliki ijin } \\
\text { operasi dari Direktorat } \\
\text { Jenderal Perhubungan Udara } \\
\text { 2. Karyawan memiliki sertifikat } \\
\text { kecakapan untuk } \\
\text { mengoperasikan peralatan } \\
\text { Ground Support Equipment } \\
\text { (GSE) } \\
\text { 3. Peralatan memiliki sertifikat } \\
\text { kelaiakan yang dikeluarkan } \\
\text { oleh Direktorat Jenderal } \\
\text { Perhubungan Udara } \\
\text { 4. Memiliki hubungan yang baik } \\
\text { dengan konsumen }\end{array}$ & $\begin{array}{l}\text { 3. Hanya melayani } \\
\text { pesawat kargo } \\
\begin{array}{l}\text { 4. Peralatan yang sudah } \\
\text { aging }\end{array}\end{array}$ \\
\hline $\begin{array}{l}\text { Peluang (Opportunities) } \\
\text { 1. Pasar bisnis yang masih } \\
\text { tinggi } \\
\text { 2. Harga layanan jasa ground } \\
\text { handling di Sentani yang } \\
\text { relatif tinggi } \\
\text { 3. Program percepatan } \\
\text { pemerintah terhadap } \\
\text { pembangunan di Papua } \\
\text { 4. Sembako, Bahan Bakar } \\
\text { Minyak (BBM) dan } \\
\text { kebutuhan lainnya di } \\
\text { angkut melalui jalur udara }\end{array}$ & $\begin{array}{l}\text { 1. Dengan perusahaan memiliki } \\
\text { ijin operasi dari Direktorat } \\
\text { Jenderal Perhubungan Udara, } \\
\text { karyawan yang memiliki } \\
\text { sertifikat kecakapan untuk } \\
\text { mengoperasikan peralatan } \\
\text { Ground Support Equipment } \\
\text { (GSE), dan peralatan } \\
\text { memiliki sertifikat kelayakan } \\
\text { yang dikeluarkan oleh } \\
\text { Direktorat Jenderal } \\
\text { Perhubungan Udara akan } \\
\text { memberikan peluang untuk } \\
\text { PT. Menara Angkasa Semesta } \\
\text { Cabang Sentani } \\
\text { mengembangkan bisnisnya. } \\
\text { Memiliki hubungan yang } \\
\text { baik dengan konsumen } \\
\text { sehingga dapat melakukan } \\
\text { negosiasi agar harga layanan } \\
\text { jasa groundhandling dapat } \\
\text { lebih tinggi }\end{array}$ & $\begin{array}{l}\text { 1. Pasar bisnis yang masih } \\
\text { tinggi dan harga jual } \\
\text { jasa ground handling di } \\
\text { Sentani yang relative } \\
\text { tinggi memberikan } \\
\text { peluang untuk } \\
\text { pimpinan PT. Menara } \\
\text { Angkasa Semesta } \\
\text { Cabang Sentani } \\
\text { berinisiatif melakukan } \\
\text { pinjaman kepada } \\
\text { investor guna } \\
\text { menambah modal, dan } \\
\text { meremajakan peralatan } \\
\text { yang sudah aging. } \\
\text { Program percepatan } \\
\text { pemerintah terhadap } \\
\text { pembangunan di Papua, } \\
\text { memberikan peluang } \\
\text { untuk keberlangsungan } \\
\text { usaha PT. Menara } \\
\text { Angkasa Semesta } \\
\text { Cabang Sentani yang } \\
\text { hanya melakukan } \\
\text { layanan jasa } \\
\text { groundhandling untuk } \\
\text { pesawat kargo }\end{array}$ \\
\hline $\begin{array}{l}\text { Ancaman (Threatsh) } \\
\text { 1. Munculnya perusahaan } \\
\text { baru dengan menawarkan }\end{array}$ & $\begin{array}{l}\text { 1. Dengan perusahaan memiliki } \\
\text { ijin operasi dari Direktorat } \\
\text { Jenderal Perhubungan Udara, }\end{array}$ & $\begin{array}{l}\text { Melakukan strategi } \\
\text { integrasi horizontal dengan } \\
\text { melakukan kerjasama }\end{array}$ \\
\hline
\end{tabular}




\begin{tabular}{|c|c|c|}
\hline $\begin{array}{l}\text { pelayanan jasa yang sama } \\
\text { 2. Peraturan pemerintah } \\
\text { yang berubah - ubah } \\
\text { 3. Pengelolaan Bandar } \\
\text { udara dikelola oleh PT. } \\
\text { Angkasa Pura I, } \\
\text { menyebabkan biaya } \\
\text { konsesi yang tinggi } \\
\text { 4. Kompetitor berani } \\
\text { bersaing dengan harga } \\
\text { yang dipatok lebih murah }\end{array}$ & $\begin{array}{l}\text { karyawan yang memiliki } \\
\text { sertifikat kecakapan untuk } \\
\text { mengoperasikan peralatan } \\
\text { Ground Support Equipment } \\
\text { (GSE), dan peralatan } \\
\text { memiliki sertifikat kelaiakan } \\
\text { yang dikeluarkan oleh } \\
\text { Direktorat Jenderal } \\
\text { Perhubungan Udara dapat } \\
\text { memitigasi adanya ancaman } \\
\text { dari perusahaan baru atau } \\
\text { kompetitor yang berani } \\
\text { bersaing dengan harga yang } \\
\text { dipatok lebih rendah, dan } \\
\text { peraturan pemerintah yang } \\
\text { berubah - ubah. } \\
\text { Karena memiliki hubungan } \\
\text { yang baik dengan konsumen } \\
\text { sehingga perusahaan dapat } \\
\text { melakukan negosiasi agar } \\
\text { konsesi yang awalnya } \\
\text { dibebankan kepada layanan } \\
\text { jasa ground handling dapat } \\
\text { ditagihkan kepada maskapai } \\
\text { penerbangan. }\end{array}$ & $\begin{array}{l}\text { dengan perusahaan } \\
\text { pesaing yang sejenis dan } \\
\text { mensinergikan kekuatan } \\
\text { yang dimiliki untuk } \\
\text { mendapatkan pangsa pasar } \\
\text { yang besar dan } \\
\text { mendongkrak modal kerja. }\end{array}$ \\
\hline
\end{tabular}

\section{Gambar 3. Matrik SWOT}

Dari hasil perhitungan table IFAS dan EFAS didapatkan nilai IFAS sebesar 2.88 dan skor untuk hasil EFAS sebesar 2.78. Apabila dikonversikan kedalam gambar diagram IE Matriks, maka terletak di kuadran $\mathrm{V}$, dimana hasilnya perusahaan masuk kedalam fase pertumbuhan dan stabilitas (growth and stability).

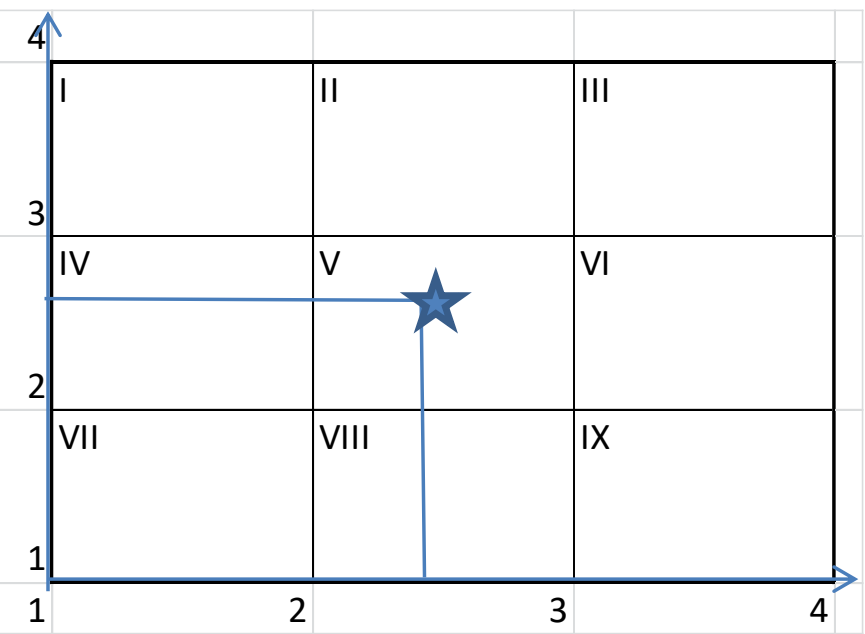

Gambar 4 Posisi Perusahaan 
Berdasarkan pada gambar 4 PT. Menara Angkasa Semesta Cabang Sentani berada pada kuadran V, dapat diketahui bahwa strategi yang sesuai bagi PT. Menara Angkasa Cabang Sentani terletak di kuadran V adalah strategi pertumbuhan dengan konsentrasi melalui integrasi horizontal. Strategi pertumbuhan melalui integrasi horizontal dari sisi internal hendaknya segmen pasar diperluas menjadi lebih besar, dan dari sisi eksternal perusahaan dapat melakukan akuisisi atau joint venture dengan perusahaan pada industri yang sama dan didukung strategi dari analisis SWOT, Wheelen dan Hunger (2012). Solusi yang dapat dilakukan PT. Menara Angkasa Semesta Cabang Sentani adalah:

1. Peningkatkan segmen pasar dengan memperluas daerah pemasaran

2. Melakukan kerjasama dengan perusahaan sejenis

3. Menjalin kerjasama yang baik dengan para konsumen

4. Mentaati prosedur dan perijinan dari regulator yaitu Direktorat Jenderal Perhubungan Udara.

\section{KESIMPULAN DAN SARAN}

Berdasarkan hasil penelitian dari sisi internal, kekuatan PT. Menara Angkasa Semesta Cabang Sentani lebih besar dibanding kelemahannya, sementara dari sisi eksternal peluang lebih besar dibanding ancaman, sehingga strategi yang sesuai adalah strategi $\mathrm{S}-\mathrm{O}$, yaitu dengan menerapkan strategi dengan memanfaatkan peluang yang ada dan memanfaatkan kekuatan yang dimiliki. Berdasarkan perhitungan matriks IFAS - EFAS, perusahaan saat ini berada pada kuadran V yang berarti PT. Menara Angkasa Semesta Cabang Sentani disarankan menerapkan strategi pertumbuhan dengan konsentrasi melalui integrasi horizontal, yang bisa dilakukan dengan cara perluasan segmen pasar, kerjasama dengan perusahaan sejenis, menjalin hubungan yang baik dengan para konsumen, serta mentaati prosedur dan perijinan dari regulator yaitu Direktorat Jenderal Perhubungan Udara.

\section{DAFTAR PUSTAKA}

Ali, Hapzi. 2020. Modul Strategic Management Program Studi Magister Management. UMB Jakarta.

Boone., Louis, E. Kurtz., David L. (2008). Pengantar Bisnis Kontemporer, Buku 1. Jakarta: Salemba Empat.

David, F.R. (2009). Strategic Management,12thed. New Jersey: Pearson Prentice Hall.

David, Fred R. (2011). Strategic Management: Concepts and Cases, 3rd ed. New Jersey:Pearson Prentice Hall.

Eddy, Y. (2016). Manajemen Strategi. Yogyakarta: Andi.

Kaplan., Norton. (2008). The Execution Premium: Linking Strategy To Operation For Competitive. Boston: Harvard Business School Publishing Corporation.

Nedelea, S., Paun, L.A. (2009). The Importance of Strategic Management Process In The Knowledge-Based economy. Review of International.

Porter, M.E. (1996). On Competition, Boston: Harvard Business School Publishing Corporation.

Rangkuti, F. (1998). Analisis SWOT Teknik Membedah Kasus Bisnis. Jakarta: PT Gramedia.

Sugiono, (2010). Metode Penelitian Bisnis. Bandung: Alfabeta.

Tjoe, T.F., Sarjono,H.(2010). Strategi Bisnis Pada PT. CTL Dengan Pendekatan Metode TOWS, Binus Business Review, 1(2), 434-447.

Umar, P. (2003). Pengolahan Data Penelitian. Jakarta: Ufuk Press. 
Utami, M. (2012). Analisis SWOT Pada Strategi Bisnis Dalam Kompetisi Pasar (Studi Kasus Toko Pajak Madura). Studi informatika : Jurnal Sistem Informasi, 5(1), 1-9.

Wheelen, T.L., Hunger, J.D. (2012). Strategic Management and Business Policy, 13thed. United States: Pearson.

Wiagustini, N.L.P., Pertamawati, N.P. (2015). Pengaruh Risiko Bisnis dan Ukuran Perusahaan Terhadap Struktur Modal dan Nilai Perusahaan Pada Perusahaan Farmasi Di Bursa eEek Indonesia. Jurnal Manajemen Strategi Bisnis dan Kewirausahaan, 9(2), 112-112. 